\title{
Variation on morphology and spore characters of Dicranopteris and Sticherus (Gleicheniaceae) from Rokan Hulu District, Riau, Indonesia
}

\author{
AFNI ATIKA MARPAUNG, RATNA SUSANDARINI \\ Faculty of Biology, Universitas Gadjah Mada. Jl. Teknika Selatan, Sekip Utara, Sleman 55281, Yogyakarta, Indonesia \\ Tel. /fax.: +62-274-580839, email: ratna-susandarini@ugm.ac.id
}

Manuscript received: 25 August 2021. Revision accepted: 26 September 2021

\begin{abstract}
Marpaung AA, Susandarini R. 2021. Variation on morphology and spore characters of Dicranopteris and Sticherus (Gleicheniaceae) from Rokan Hulu District, Riau. Biodiversitas 22: 4475-4486. Dicranopteris and Sticherus are genera in the family Gleicheniaceae which have unique habits and distinctively specific growth with the presence of a bud on the forking branches. This study aims to reveal the species diversity of Gleicheniaceae members found in the forest area of Bukit Suligi Tandun, Rokan Hulu District, Riau and to document variations in their morphological characters and spores. Eleven collections were obtained from the exploration in the study area. The identification of plant specimens showed that these eleven taxa consisted of Dicranopteris curranii, Dicranopteris speciosa, seven varieties of Dicranopteris linearis, and two varieties of Sticherus truncatus. Seven varieties within D. linearis were $D$. linearis var. linearis, D. linearis var. alternans, D. linearis var. altissima, D. linearis var. demota, D. linearis var. inaequalis, D. linearis var. subspeciosa, and D. linearis var. tetraphylla. The only one species of Sticherus found was $S$. truncatus which consisted of two varieties, namely $S$. truncatus var. truncata and $S$. truncatus var. involuta. Morphological characters were observed from fertile specimens, while spore characters were observed from spore microscopic slides prepared using acetolysis method. There were 42 morphological characters and spores examined and used as the basis for determining the phenetic relationships using cluster analysis and principal component analysis. The results of cluster analysis showed the formation of two clusters that clearly separated the genus Sticherus from Dicranopteris. The three species of Dicranopteris were also clearly separated from each other in different subclusters. The result of principal component analysis indicated characters that contribute to the grouping of the eleven taxa and was able to explain the distinguishing characters in each group recognized from the cluster analysis. Overall, the results of this study contributed to documenting in detail the morphological variations in sporophyte and spore characters in eleven taxa of Dicranopetris and Sticherus, as well as proving the role of morphological and spore characters in the classification and defining phenetic relationships using numerical taxonomic approach.
\end{abstract}

Keywords: Forking ferns, palynology, phenetics, sporophyte, taxonomic relationship

\section{INTRODUCTION}

Gleicheniaceae is a family of primitive and ancient ferns with its existence on the Earth was marked by the first appearance of mega fossil evidence in the Permian (Skog 2001). The classification of Gleicheniaceae continues to develop with the integration of increasingly more taxonomic evidence, and currently, the classification widely accepted is the system developed by Smith et al. (2006) which recognized six genera within the family. Christenhusz and Chase (2014) had the same opinion in recognizing six genera in Gleicheniaceae. The six genera are Dicranopteris, Gleichenella, Diplopterygium, Gleichenia, Sticherus, and Stromatopteris. The recognition of these six genera was adopted in the current classification system by the Pteridophyte Phylogeny Group (PPG I 2016). Despite the agreement on the number of genera within the family, taxonomic revisions on the placement of some species into particular genus are still very dynamic. In this regard, Perrie (2018) reported a change in the status of Gleichenia hooglandii from Papua New Guinea to different genus, Sticherus. Similarly, recent study on Gleichenia boryi based on morphological and molecular data lead to the recognition of Rouxopteris as an endemic genus to the Madagascar region (Liu et al. 2020).

Some species in Gleicheniaceae have high morphological variations as indicated by the presence of intraspecific categories, such as Dicranopteris linearis with 13 varieties found in Southeast Asia (De Winter and Amoroso 2003). This high species variability is evident from its morphology which becomes the basis for identification and classification at below species level. Until now morphology is still used as the basis for identification, classification, and even for phylogeny reconstruction although various molecular techniques are available. This also applies to ferns, in that the results of phylogenetic analysis based on morphology and molecular data showed similar patterns of relationships (Schneider et al. 2009). The role of morphology as the basic taxonomic evidence for species determination is still relevant, and still has an important role in phylogenetic reconstruction (Pochynok 2012). Accordingly, the exploration of morphological characters in ferns and their role in determining taxonomic relationships reported in this study is relevant and provides important contribution in plant systematics. 
The importance of exploratory research on the diversity of ferns was proven by a number of studies on this topic that have been carried out in the Sumatra region. The study of Beukema et al. (2013) on ferns diversity in relation to the quality of agroforest habitats in Sumatra showed there were two Dicranopteris species that can be used as indicators of forest disturbance and ecological restoration. In this regard, Dicranopteris linearis var. linearis was one of fern species identified as indicator of highly to moderately disturbed early succession habitat. Meanwhile, Dicranopteris linearis var. subpectinata was identified as fern species indicating moderate disturbance. A study on the diversity of ferns in Lubuak Mato Kuciang as an area developed for tourism in West Sumatra showed the presence of two species belonging to the Gleicheniaceae, namely Dicranopteris linearis and Gleichenia linearis (Diliarosta et al. 2020). Studies on the diversity of ferns in another region in Southeast Asia were also reported by a number of researchers, some of which also revealed the presence of species belonging to the Gleicheniaceae. Nazihah et al. (2018) in a study on the diversity and distribution of ferns in Kuantan Pahang, Malaysia reported the presence of Dicranopteris linearis as one of 14 species found in open areas in forest. Research on the diversity of ferns as the basis for producing a checklist in two tourism forests in Kedah, Malaysia by Rahmad and Akomolafe (2019) found two species of Gleicheniaceae, namely Dicranopteris linearis and Gleichenia truncata. A study to uncover ferns that were classified as threatened was carried out by Coritico and Amoroso (2020) which served as a basis for protection and conservation, as well as growing public awareness of the diversity of ferns that need to be protected. Recently, Saharizan et al. (2021) investigated the species composition, diversity, and species richness of ferns in oil palm plantation areas in Segamat, Johor. One species belonging to the Gleicheniaceae that was recorded at the study sites was Dicranopteris linearis.

Gleicheniaceae is unique in terms of its leaf morphology as characterized by a pseudodichotomous branching pattern that produces a forking architecture, and the presence of buds on older branches resulted in indeterminate leaf growth. This unique pattern of branching and leaf growth generated specific terminology applied to this family (Shaw and Ranker 2011; Gonzales and Kessler 2011). The uniqueness of Gleicheniaceae morphology is attractive by which some species were used as ornamental plants. Dicranopteris linearis, known as a scrambling fern, is one of species used as ornamental plants (De Winter and Amoroso 2003). Dicranopteris also has important ecological functions due to its rapid clonal growth ability to fill gaps after disturbance and to facilitate habitat succession, and able to reduce soil erosion due to rainfall (Yang et al. 2021). With these various biological roles, it is very interesting to study the species diversity in the Gleicheniaceae family.

Spore is part of gametophyte generation in ferns which will germinate to produce free-living prothallium. The morphology of fern spores shows specific features and thus might serve as a diagnostic tool for identification and classification (Adeonipekun et al. 2021). Several studies have proven the important role of spores in fern taxonomy. Regalado and Sánchez (2002) reported that spore morphology was proven to be useful in the identification and delimitation of three Asplenium species. A study by Passareli et al. (2010) on the genus Blechnum showed that spore characteristics combined with morphological characters of the sporophyte were complementary in defining specific taxonomic characters at species level. Similarly, Chao and Huang (2018) in their systematic study of the genus Pteris mentioned that combination of spore morphology and leaf characters was useful in infrageneric classification. Results of those studies become the basis for the use of spore morphology along with sporophyte morphological characters in determining taxonomic relationships between members of Dicranopteris and Sticherus in this study.

Until recently there was no comprehensive study on Gleicheniaceae in Indonesia. Publications on the existence of Gleicheniaceae species were only available from studies on fern diversity in general, and not only focused on this family. The records on small number of Gleicheniaceae species were found from exploration studies in Enggano Island (Wardani and Adjie 2017), in Siberut National Park, West Sumatra (Mildawati et al. 2020), in five mountains in West Java (Suryana et al. 2020), and in Mount Gede Pangrango National Park, West Java (Andriyani and Nurza 2021). The objective of this study was to reveal the species diversity of the members of Gleicheniaceae in the Rokan Hulu, Riau. This study also aimed to document variations in morphology and spore characters as well as their role in determining phenetic relationships of two genera within Gleicheniaceae namely Dicranopteris and Sticherus.

\section{MATERIALS AND METHODS}

\section{Study area, collection of plant samples, and species identification}

Plant materials for this study were obtained from the exploration of Bukit Suligi Tandun, Rokan Hulu District, Riau, Indonesia (Figure 1). The plant specimens were collected from their natural habitat by exploring along Jalan Raya Dayo as the only access road in the area (Figure 2). The collected specimens were fertile adult plants that were recognized based on their morphology as members of Gleicheniaceae. The fertile frond containing sori were kept separately in zip-lock plastic bag as materials for preparing spore microscopic slides. The methods of collecting plant samples and making herbarium specimens referred to the procedures of Bean (2010). Identification of specimens was carried out with reference to Holtum (1957; 1959). Verification of species names and their author was carried out by referring to the Plants of the World Online database (http://www.plantsoftheworldonline.org/). 

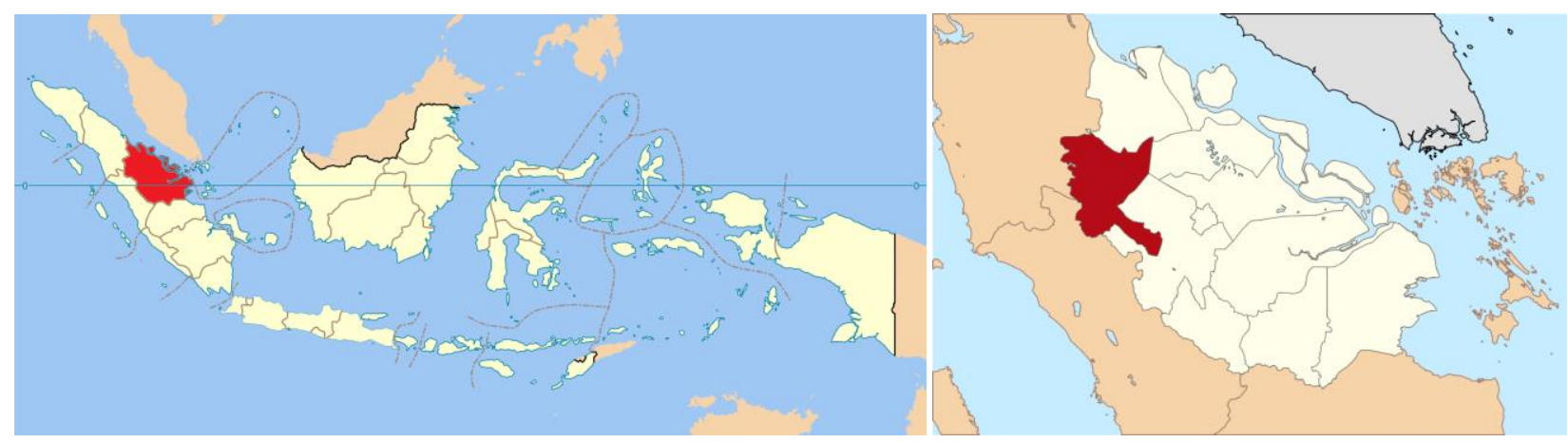

Figure 1. Location of Rokan Hulu District, Riau Province, Indonesia
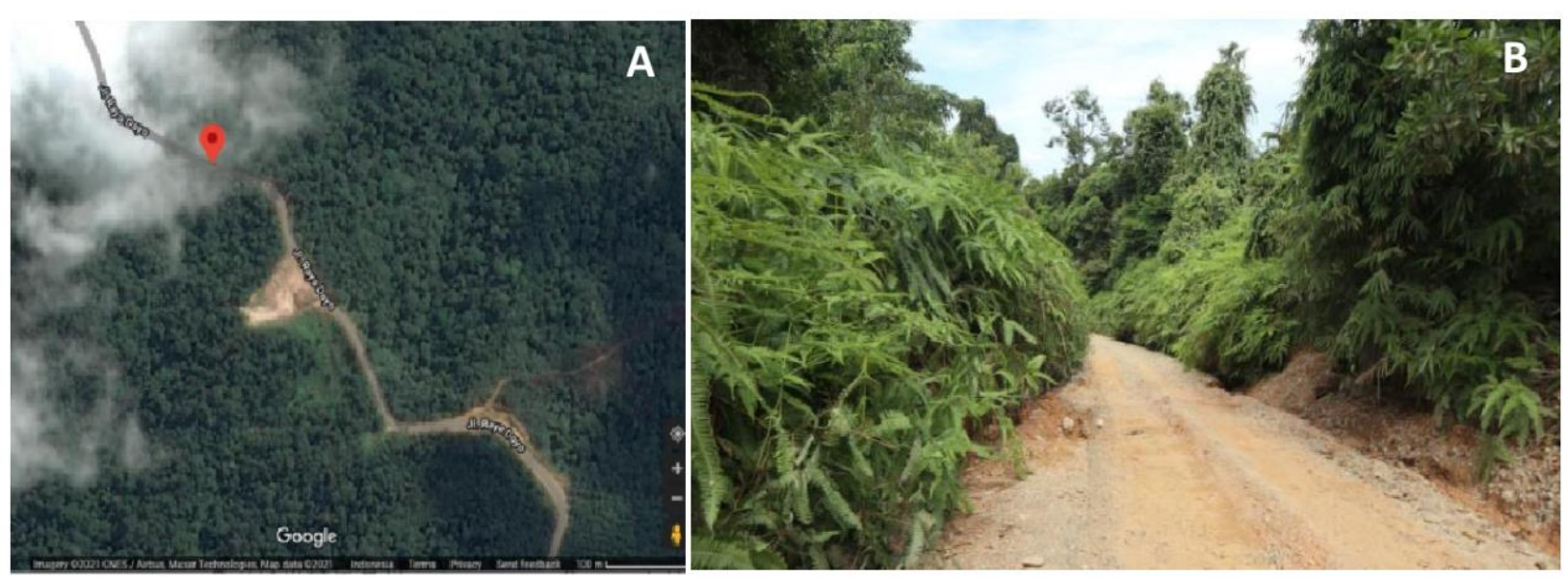

Figure 2. Location of plant samples collection: A. Aerial map of Bukit Suligi Tandun, B. Jalan Raya Dayo

\section{Preparation of spore microscopic slides}

Preparation of spore microscopic slides was carried out using the acetolysis method as described by Jones (2014). The observations and documentation of spore morphological characters were performed using light microscope equipped with an OptiLab microscope camera at a magnification of $10 \times 40$. Six morphological characters of spores were examined namely spore type, spore shape, the length of polar axis $(\mathrm{P})$, the diameter equatorial plane (E), spore size class based on P/E ratio, and exine ornamentation. Observations and measurements of spore morphological characters were done on 10 spores in each sample. The terminology used for defining spore morphological characters referred to Punt et al. (2007).

\section{Analysis of taxonomic relationships}

Analysis of taxonomic relationships of the taxa under study was performed based on morphological and spore characters. Cluster analysis to construct the dendrogram was done by calculating Euclidean distance and employing Unweighted Pair Group Method with the Arithmetic mean (UPGMA) clustering method. Principal component analysis was carried out to find hypothetical variables accounted for. for the variance in the data. The results of principal component analysis were presented as eigenvalues and eigenvectors. This two multivariate analyses were done using PAST 3.20 (Hammer et al. 2001).

\section{RESULTS AND DISCUSSION}

\section{Species diversity of Dicranopteris and Sticherus from Rokan Hulu}

Based on the exploration along the road on Bukit Suligi Tandun Forest, 11 fern specimens belong to Gleicheniaceae family were found. The species identification based on morphological characters showed that these specimens consisted of two genera namely Dicranopteris and Sticherus (Table 1). There were three species of Dicranopteris recognized in this study, D. curranii, $D$. speciosa, and the most variable one $D$. linearis with seven varieties. Meanwhile, two other specimens were identified as Sticherus truncatus var. truncata and S. truncatus var. involuta. 
Table 1. List of Dicranopteris and Sticherus species and varieties found in Rokan Hulu District, Riau, Indonesia

\begin{tabular}{ll}
\hline Genus & Species and varieties \\
\hline Dicranopteris & Dicranopteris linearis (Burm. f.) Underw. var. \\
& altissima Holttum \\
& D. linearis var. inaequalis (Rosenst.) Holttum \\
& D. linearis var. linearis \\
& D. linearis var. demota Holttum \\
& D. linearis var. alternans (Mett.) Holttum \\
& D. linearis var. tertraphylla (Rosenst.) Nakai \\
& D. linearis var. subspeciosa Holttum \\
& D. curranii Copel. \\
& D. speciosa (Presl) Holttum \\
& Sticherus truncatus (Willd.) Nakai var. involuta \\
& Holttum \\
Sticherus & S. truncatus var. truncata \\
&
\end{tabular}

Morphological Variability of Dicranopteris and Sticherus

The members of Dicranopteris and Sticherus found in this study showed notable variation in the pinna (plural: pinnae) morphology (Figure 3). Following the specific leaf terminology applied for Gleicheiaceae, pinna is the primary division of the leaf. Sticherus was characterized by pinnae that are indistinguishable from accessory costa, which is the major axis of the accessory leaflets. Dicranopteris, on the other hand, showed variations in the pinnae morphology, especially the size of the pinnae. The longest and widest pinnae were found in D. curranii $(55 \mathrm{~cm}$ long and $11 \mathrm{~cm}$ width), while the smallest pinnae were found in D. linearis var. subspeciosa (14 cm long and $5 \mathrm{~cm}$ width). It was obvious, therefore, that pinnae morphology was one of the characters distinguishing Sticherus from Dicranopteris, and the characters differentiating between species of the latter genus.

The variation on pinna morphology identified in this study as distinguishing characters between species was in line with results of morphological studies in other fern genera. Jaman et al. (2018) showed that pinna size, pinna scale size, venation pattern, and sorus position on sporophylls were used as the basis for recognizing different Asplenium species. The characters of the pinna apex and hairs on the abaxial surface of the pinna and rachis were among the morphological characters used by Shepherd et al. (2019) to recognize differences between Dicksonia fibrosa and D. lanata, and at the same time were used as the basis for affirming the identity and status of the hybrid between the two species.

Detailed observations on pinnules, that is the smallest or last order of division of pinna, showed variations on their veins. The veins showed differences in the number forking which varied from once, twice, three times, and four times (Figure 4). Once-forked veins were found only in Sticherus, whereas the members of Dicranopteris showed high variations on the forking patterns of veins. Twice-forked veins was found in $D$. linearis var. inaequalis, D. linearis var. alternans, D. linearis var. var tertraphylla, D. linearis var. var subspeciosa, and $D$. speciosa. Veins of three times-forked was found in $D$. linearis var. altissima, D. linearis var. linearis, and D. linearis var demota, while four times-forked vein pattern was found only in D. curranii. Previous studies have mentioned that the number of forking in veins of the pinnules or ultimate leaflet was the key characteristics that distinguishes the genus Dicranopteris from Sticherus (Chinnock and Bell 1998; Jin et al. 2013). Moreover, Perrie and Brownsey (2015) confirmed that one of the distinguishing characters between Dicranopteris and Sticherus was the branching pattern of venation located between the midvein and the margin on the ultimate segment or pinnules. Vein character was also reported for distinguishing species in the genus Tectaria (Dong et al. 2020).

Another noticeable morphological variation that distinguished Sticherus from Dicranopteris was the protective structure on rachis bud (Figure 5). The rachis bud is a bud borne at the apex of rachis flanked by two pinnae, and there were variations on the stipules found on rachis bud. Stipules are protective structures on rachis buds when they are dormant. Stipule morphology also varied in three species of Dicranopteris, and even showed variations between different varieties within $D$. linearis. Østergaard and Øllgaard (1996) noted that stipules in Gleicheniaceaeeae can be flat, forked, lobed, or pinnatifid leaf-like structures. Stipules found on the rachis bud of Sticherus truncatus have unique shapes that did not resemble leaflets (Figure 5.A, 5.B), whereas leaf-like stipules were found in D. curranii (Figure 5.C). The presence of two small lobe-shaped stipules characterized the rachis buds of $D$. linearis var. altissima, $D$. linearis var. linearis, D. linearis var. demota, D. linearis var tertraphylla and D. speciosa. Two large lobed stipules as protective structures on rachis bud were found in $D$. linearis var. inaequalis, D. linearis var. alternans, and $D$. linearis var. subspeciosa (Figure 5.E, 5.I, 5.K).

Variation of stipules on rachis buds was one of the morphological characters used for species identification of ferns, as mentioned by Lima and Salino (2018) that within the genus Sticherus there were species that have stipules and the others do not have stipules. The morphology of the rachis buds as a distinguishing character between fern genera was reported by Perrie and Brownsey (2015) in which the members of Gleicheniaceae have rachis buds protected by either pseudostipules or accessory leaflets. In addition to characteristics of the stipules, the rachis buds in Dicranopteris and Stricherus also showed differences in the presence of hairs and scales that protect the rachis buds.

A prominent morphological variation found in three species and seven varieties of Dicranopteris and two varieties of Sticherus truncatus was the number of sporangia composing the sorus (plural: sori) as shown in Figure 6. It was obvious that the number of sporangia per sorus was one of the most conspicuous characters that distinguished the genus Dicranopteris from Sticherus. The sorus in two varieties of $S$. truncatus consisted of four sporangia, while the three species of Dicranopteris showed variations in the number of sporangia per sorus ranging from 7 to 17 . This result was similar to previous records on Dicranopteris and Sticherus in other countries as mentioned by Chinnock and Bell (1998), and Jin et al. (2013). In this regard, Perrie and Bownsey (2015) noted that in New Zealand the number of sporangia per sorus in Dicranopteris was 7-12, while Sticherus had 3-5 sporangia per sorus. 


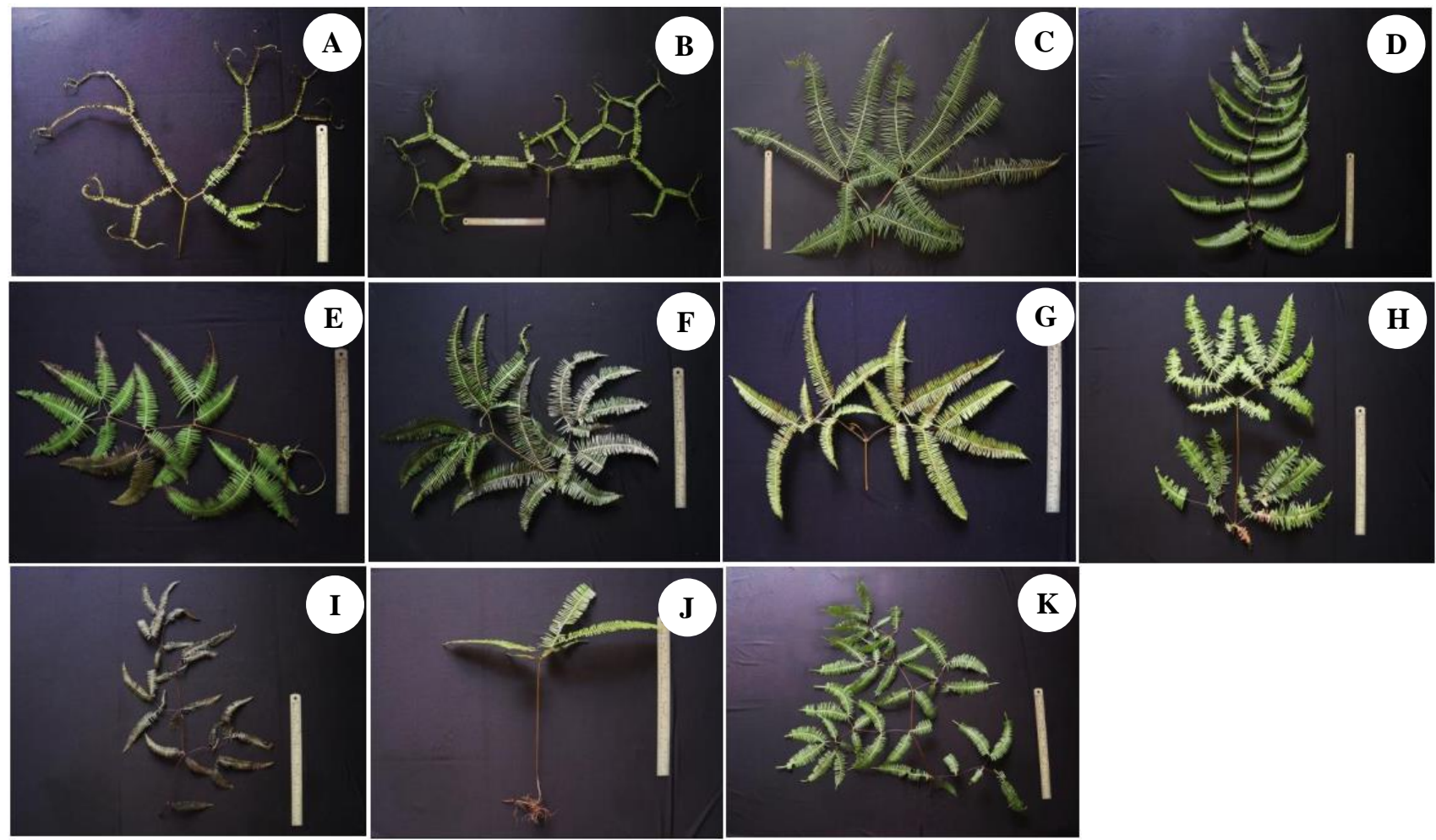

Figure 3. Variation on pinna morphology. A. Sticherus truncatus var. involuta, B. S. truncatus var. truncata, C. Dicranopteris curranii, D. D. speciosa, E. D. linearis var. inaequalis, F. D. linearis var. altissima, G. D. linearis var. linearis, H. D. linearis var. demota, I. D. linearis var. alternans, J. D. linearis var. tetraphylla, K. D. linearis var. subspeciosa
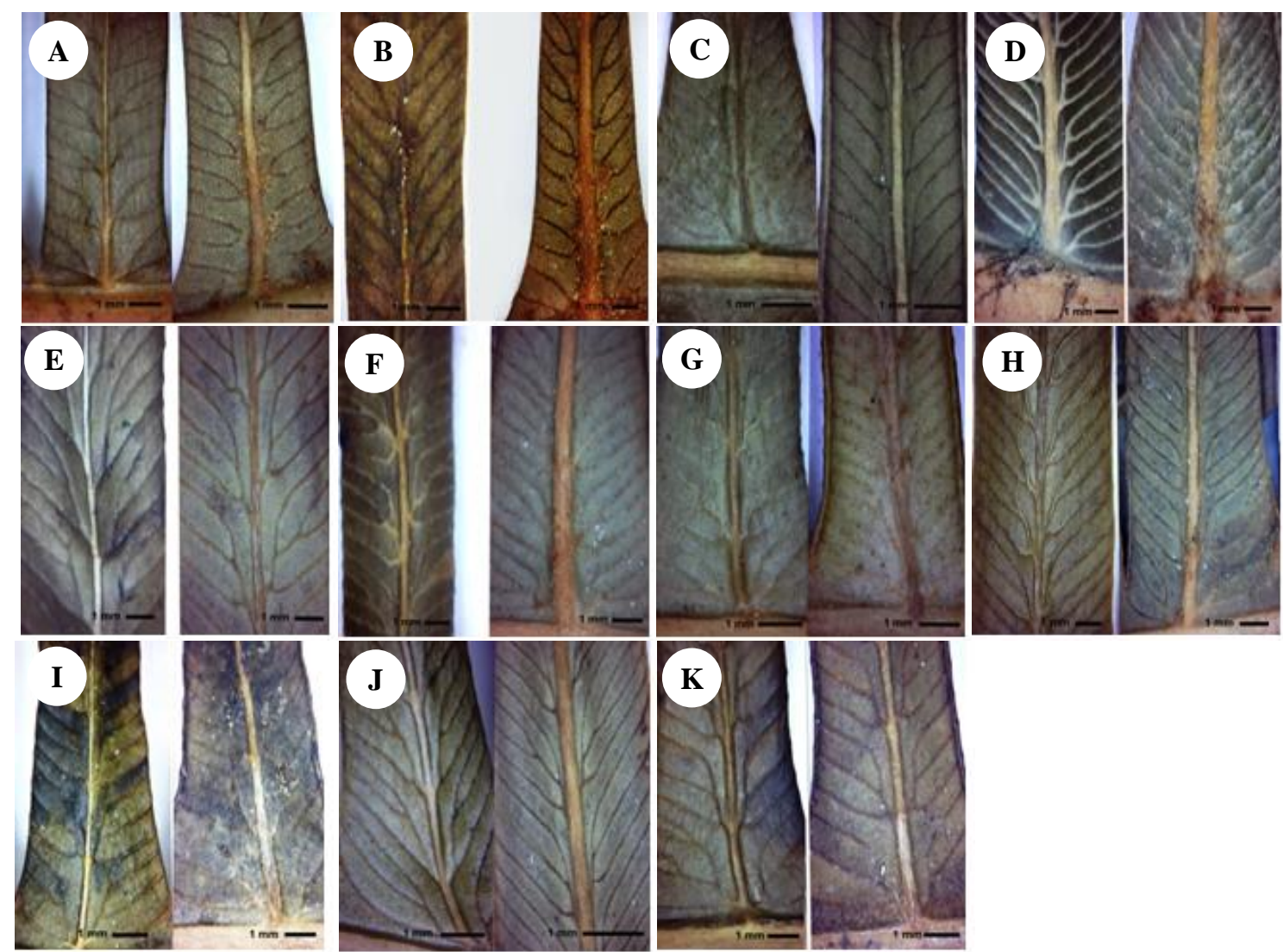

Figure 4. Variation on veins forking patterns of the pinnules. A. Sticherus truncatus var. involuta, B. S. truncatus var. truncata, C. Dicranopteris curranii, D. D. speciosa, E. D. linearis var. inaequalis, F. D. linearis var. altissima, G. D. linearis var. linearis, H. D. linearis var. demota, I. D. linearis var. alternans, J. D. linearis var. tetraphylla, K. D. linearis var. Subspeciosa 

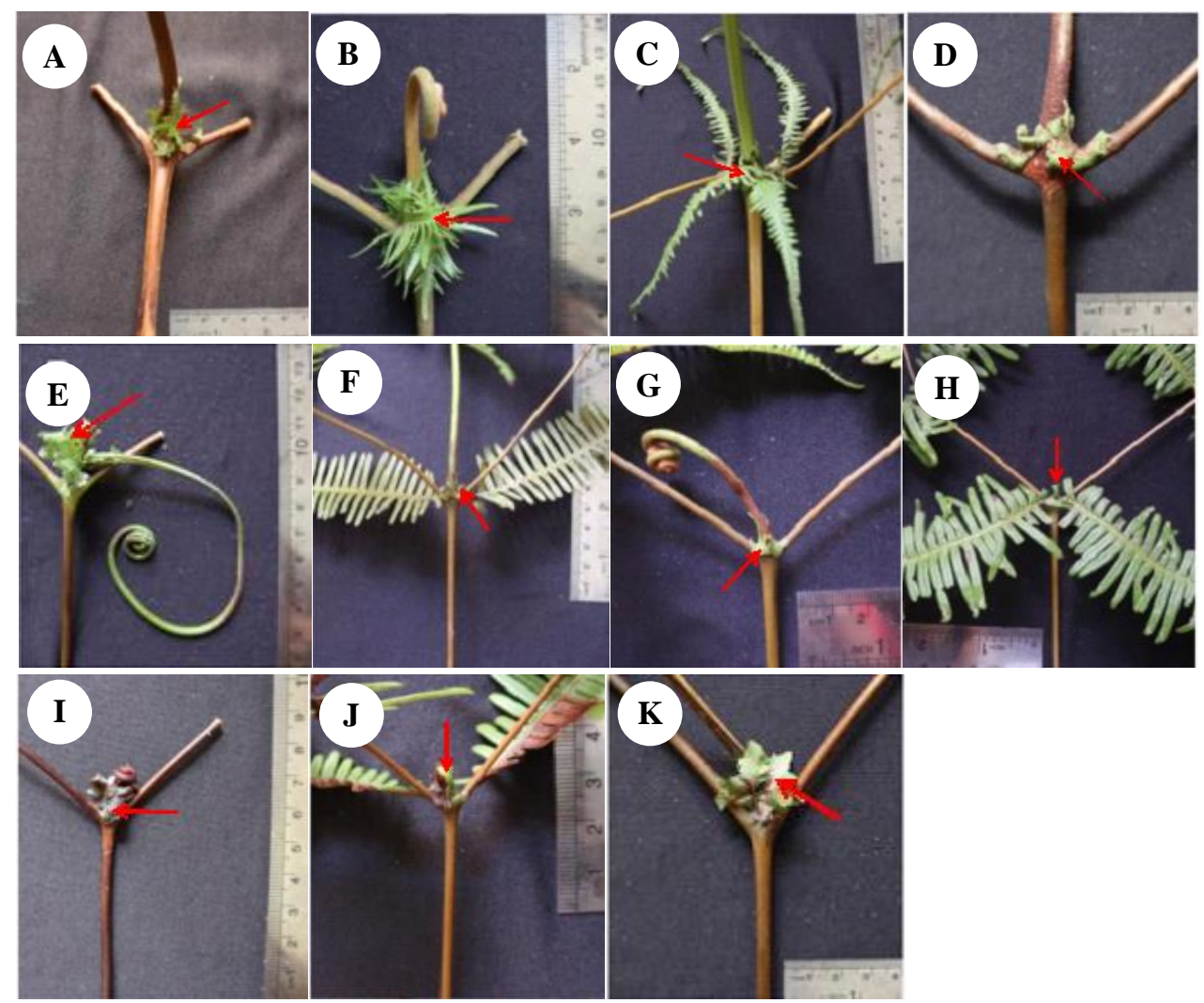

Figure 5. Variation on rachis bud protective structure (stipules). A. Sticherus truncatus var. involuta, B. S. truncatus var. truncata, C. Dicranopteris curranii, D. D. speciosa, E. D. linearis var. inaequalis, F. D. linearis var. altissima, G. D. linearis var. linearis, H. D. linearis var. demota, I. D. linearis var. alternans, J. D. linearis var. tetraphylla, K. D. linearis var. Subspeciosa
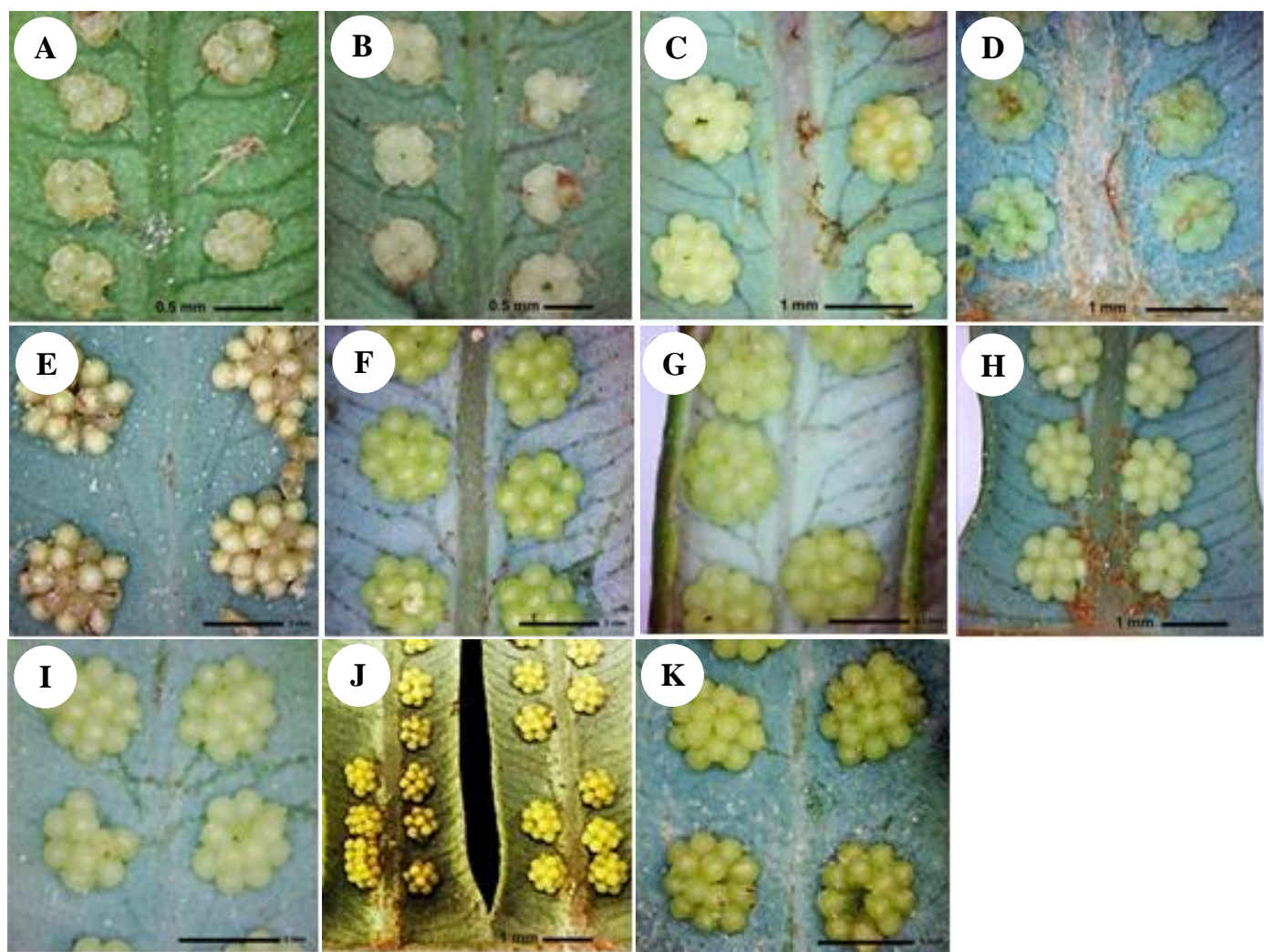

Figure 6. Variations in fern sori morphology. A. Sticherus truncatus var. involuta, B. S. truncatus var. truncata, C. Dicranopteris curranii, D. D. speciosa, E. D. linearis var. inaequalis, F. D. linearis var. altissima, G. D. linearis var. linearis, H. D. linearis var. demota, I. D. linearis var. alternans, J. D. linearis var. tetraphylla, K. D. linearis var. Subspeciosa 


\section{Spore morphology}

Spores as part of gametophyte generation in fern life cycle are having important role in sexual reproduction. Spores on 11 taxa in this study showed considerable morphological variations. There were six morphological characters of spores examined, namely spore type, the length of polar axis, the diameter of equatorial plane, spore shape, spore class based on size, and exine ornamentation. The six spore morphological characteristics of species and varieties under study were shown in Table 2. Photomicrographs of spores observed under light microscope were displayed in Figure 7.

Spore type was determined based on the presence of laesura, in which spores without any laesura were called as alete, spores with one laesura were called as monolete, and those with three laesura were classified as trilete (Punt 2007). There were two types of spores found in specimens observed in this study, the monolete and trilete spores. Sticherus truncatus had monolete spores, while three species in Dicranopteris showed variations, with monolete spores were found in $D$. curranii and trilete spores were found in $D$. speciosa and $D$. linearis. Variations in spore types in various genera and species within the Gleicheniaceaeeae family were common, as reported by Farfán-Santillán (2017) that Gleichenella pectinata and Stricherus bifidus have monolete spores, while Diplopterygium bancroftii and $D$. flexuosa have trilete spores. Variations in spore types in the same genus were also found in Aspenium (Lashin 2012) in that $A$. aethiopicum, A. trichomanes, and A. adiantum-nigrum had monolete spores while Asplenium sp.1 had trilete spores.

The size of spores observed in this study was obtained based on measurements of the length of polar axis $(\mathrm{P})$ and the diameter of equatorial plane (E). Determination of spore size classes referred to the classification of Halbritter et al. (2018) who divided spores into five classes of size based on the P/E ratio. The spores of the eleven taxa examined in this study were classified into two categories, namely small spores $(10-24 \mu \mathrm{m})$ which were only owned by $D$. curranii, and spores in the medium size $(25-49 \mu \mathrm{m})$ which belonged to the other ten taxa. In general, spores of members of Dicranopteris were smaller than those of Sticherus. Adeonipekun et al. (2021) who studied spore characteristics of various fern families noted that spore morphology was important in resolving classification of ferns and proposed the use of spore P/E ratio as diagnostic taxonomic tools in Pteridophyte.

Exine ornamentation is a spore morphological character that showed considerable variations, ranging from psilate, micro-scabrate, scabrate, to verrucate (Table 2). This study showed both intraspecies and interspecies variations on exine ornamentation. Intraspecies variation in exine ornamentation has been reported in two varieties of Adiantum reniforme, in which spores of $A$. reniforme var. reniforme had psilate ornamentation while spores of $A$. reniforme var. sinense had rugate ornamentation (Wang et al. 2015). Variations of exine ornamentation in species of the genus Dicranopteris have been reported in several studies such as those by Farfán-Santillán (2017) and Sofiyanti et al. (2019). These studies showed that the spores of $D$. flexuosa had scabrate ornamentation, while $D$. bancroftii, $D$. linearis, and $D$. medusae had psilate ornamentation. The important role of spore morphology in species delimitation has been proven by Mazumdar (2018), that based on a very notable difference in exine ornamentation confirmed that Lygodium giganteum was a distinct species and not a synonym for $L$. yunnanense as previously thought. Interspecies variation on spore ornamentation is also found in other fern genera such as those reported by Passarelli et al. (2010) in genus Blechnum and $\mathrm{Li}$ et al. (2020) in genus Ceratopteris.

Table 2. Spore morphological characters

\begin{tabular}{|c|c|c|c|c|c|c|}
\hline \multirow[b]{2}{*}{ Species and varieties } & \multicolumn{6}{|c|}{ Characters } \\
\hline & Spore type & $\begin{array}{c}\text { Length of } \\
\text { polar axis } \\
(\mu \mathrm{m})^{*}\end{array}$ & $\begin{array}{l}\text { Length of } \\
\text { equatorial } \\
\text { axis }(\mu \mathrm{m}) *\end{array}$ & $\begin{array}{c}\text { Spore } \\
\text { shape** }^{* *}\end{array}$ & $\begin{array}{c}\text { Class of } \\
\text { spore size }{ }^{* *}\end{array}$ & $\begin{array}{c}\text { Exine } \\
\text { ornamentation }\end{array}$ \\
\hline Sticherus truncarus var. involuta & Monolete & 34.14 & 18.11 & Prolate & Medium & Psilate \\
\hline Sticherus truncatus var. truncata & Monolete & 36.73 & 18.64 & Prolate & Medium & Micro-scabrate \\
\hline Dicranopteris curranii & Monolete & 24.12 & 14.00 & Prolate & Small & Psilate \\
\hline Dicranopteris speciosa & Trilete & 25.72 & 24.39 & $\begin{array}{l}\text { Prolate- } \\
\text { spheroidal }\end{array}$ & Medium & Scabrate \\
\hline Dicranopteris linearis var. inaequalis & Trilete & 33.22 & 33.06 & $\begin{array}{l}\text { Oblate- } \\
\text { spheroidal }\end{array}$ & Medium & Verrucate \\
\hline Dicranopteris linearis var. altissima & Trilete & 32.21 & 25.69 & Sub-prolate & Medium & Psilate \\
\hline Dicranopteris linearis var. linearis & Trilete & 31.43 & -23.56 & Prolate & Medium & Psilate \\
\hline Dicranopteris linearis var. demota & Trilete & 32.91 & 26.80 & Sub-prolate & Medium & Psilate \\
\hline Dicranopteris linearis var. alternans & Trilete & 31.76 & 27.35 & Sub-prolate & Medium & Micro-scabrate \\
\hline Dicranopteris linearis var. tetraphylla & Trilete & 30.72 & 28.90 & $\begin{array}{l}\text { Prolate- } \\
\text { spheroidal }\end{array}$ & Medium & Psilate \\
\hline Dicranopteris linearis var. subspeciosa & Trilete & 30.46 & 25.34 & Sub-prolate & Medium & Verrucate \\
\hline
\end{tabular}

Note: *based on average of 10 measurements; **determined based on Erdtman (1986) 

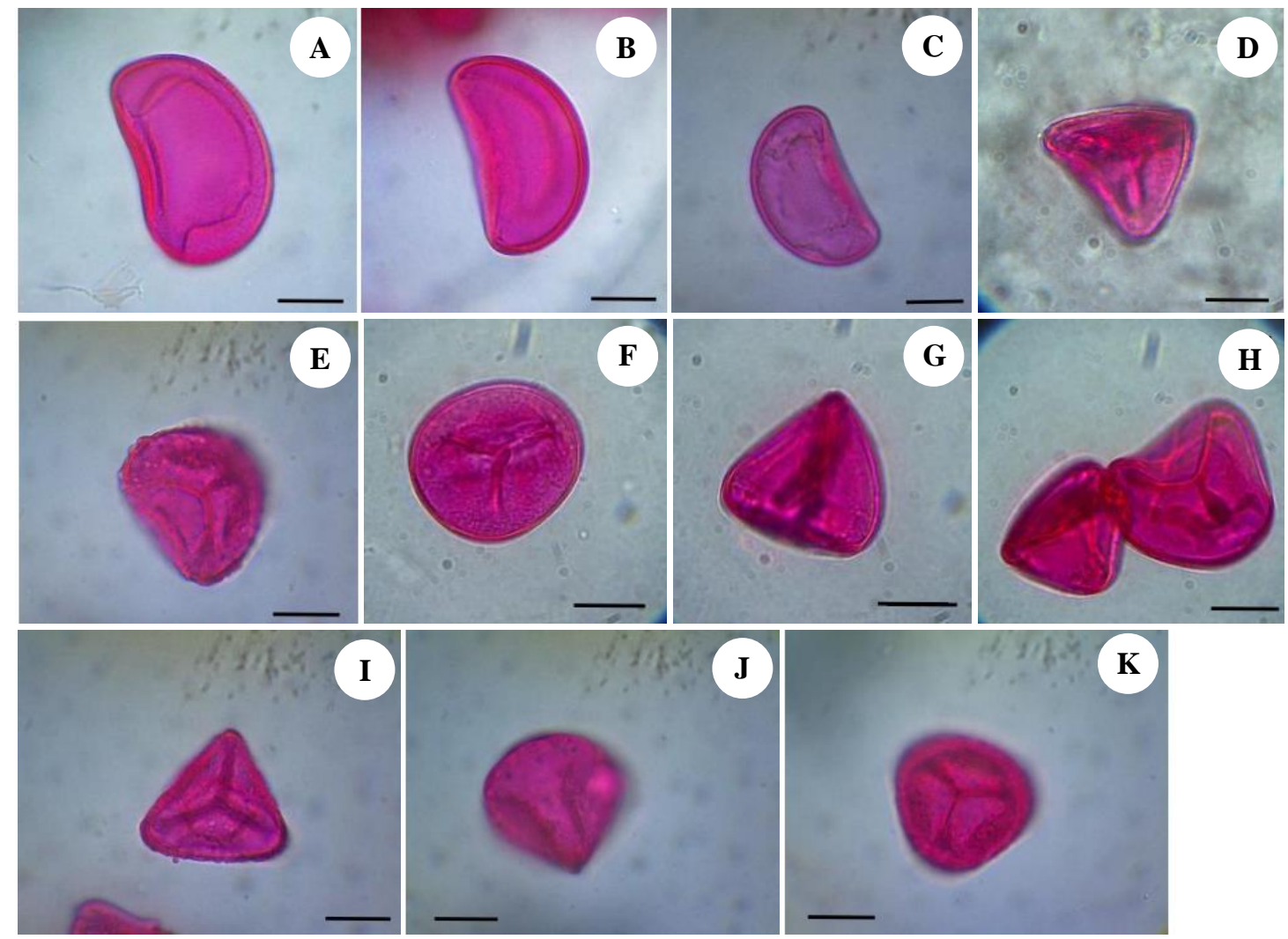

Figure 7. Light microscopic photomicrograph of spores (bar: $10 \mu \mathrm{m}$ ). A. Sticherus truncatus var. involuta, B. S. truncatus var. truncata, C. Dicranopteris curranii, D. D. speciosa, E. D. linearis var. inaequalis, F. D. linearis var. altissima, G. D. linearis var. linearis, H. D. linearis var. demota, I. D. linearis var. alternans, J. D. linearis var. tetraphylla, K. D. linearis var. subspeciosa

\section{Phenetic Relationships of species and varieties of Dicranopteris and Sticherus}

In order to determine the taxonomic relationships between three species of Dicranopteris along with its seven varieties and two varieties of Sticherus truncatus, a cluster analysis was performed based on 42 characters. The characters used in this analysis consisted of 26 morphological characters of sporophytes (plant specimens) and 6 spore characters (Table 3).

The result of cluster analysis was presented in a dendrogram (Figure 8) which showed the existence of two main clusters. The first cluster was consisted of two varieties of $S$. truncatus, whereas the second cluster consisted of nine taxa within the genus Dicranopteris. The dendrogram also showed a clear division of three species of Dicranopteris, in which D. curranii and D. speciosa were well separated from all seven varieties of $D$. linearis which formed a solid group in a distinct sub-cluster. The phenetic relationships as presented in the dendrogram confirmed the differences between two genera observed in this study and showed a clear separation between three Dicranopteris species. This result confirmed that cluster analysis was a useful tool for classification and for defining relationships of plant species (Ugwuanyim 2000; Manoko 2018). The cophenetic correlation coefficient of the dendrogram was 0.926. This coefficient was used to measure degree of fit of classification and a criterion for evaluating the efficiency of clustering techniques (Saraçli et al. 2013). The coefficient value of greater than 0.8 for the dendrogram in this study indicated that the clusters generated from the analysis was very good in terms of representing the original distance matrix or degree of resemblance between samples (Albuquerque et al. 2016).

In addition to cluster analysis, the principal component analysis was performed to identify characters that contributed to the grouping of species and varieties figured out from cluster analysis. The result of principal component analysis was presented in Table 4 which listed the character loadings and eigenvalues in the first two principal components. The eigenvalues indicated the variance accounted for by the corresponding principal components or eigenvectors. Principal component analysis has been known as complementary to cluster analysis (Mulima et al. 2018). Therefore, combination of these two methods was commonly applied in plant systematics studies in various plant taxa at any taxonomic level, from species (Fitriana and Susandarini 2019; Singh et al. 2020), genus (Alzahrani et al. 2021), to family (Arogundade and Adedeji 2019). Due to the effectiveness of these two multivariate analysis methods, cluster analysis and principal component analysis have also been applied in systematics studies of ferns such as for species delimitation in the genus Lemmaphyllum (Wei and Zhang 2013) and for determining the species relationships in Selaginella (Bautista et al. 2018). 
Observations on the character loadings of the first component showed that there were seven characters most responsible for the variance as indicated by the absolute value of higher than 0.2 . This cut-off value indicated that the characters having loadings of 0.2 were considered acceptable variables that explain at least $20 \%$ of variance (Santos et al. 2019). These seven characters were those that contributed to the separation of genus Sticherus from Dicranopteris as shown in the dendrogram generated by cluster analysis. These characters were the number of primary forks, distance between pinnules, pinnule's apex, position of sori on the pinnule, spore shape, and exine ornamentation. Observation on the second principal component showed there were six characters that had loadings higher than 0.2 . These characters were identified as those that contributed to the separation of $D$. speciosa and $D$. curranii from all members of $D$. linearis as shown in the dendrogram. These six characters were rachis bud protective structure (stipules), branch surface, the number of branches at each forking, distance between pinnules, and hairs color on pinna abaxial surface. Results of principal component analysis showed that the number of characters distinguishing genera was greater than those separating species within a genus. This was in line with the general principle of hierarchical classification in which the higher the taxonomic ranks the greater the number of characters differing between taxa (Singh 2010; Simpson 2019).

Table 3. List of characters used in cluster analysis and principal component analysis

\begin{tabular}{|c|c|c|}
\hline No & Characters & Character states or unit \\
\hline 1. & Plant habit & Erect; climbing \\
\hline 2. & Height of the first branch & Measurement (cm) \\
\hline 3. & The number of primary forks & Number (1-6) \\
\hline 4. & Stipule on the first branch & Present; absent \\
\hline 5. & Distance between branches & Measurement (cm) \\
\hline 6. & Angle of the primary branch & Degree \\
\hline 7. & Rachis bud's surface & Hairy; scaly \\
\hline 8. & Rachis bud's protective structure & Two or many stipules \\
\hline 9. & Branching pattern & Equal; unequal \\
\hline 10. & Branch surface & Glabrous/smooth, hairy \\
\hline 11. & Accessory branches & Present; absent \\
\hline 12. & Accessory leaflets & Present, absent \\
\hline 13. & Number of branches at each fork & Number \\
\hline 14. & Length of primary pinnae & Measurement (cm) \\
\hline 15. & Width of primary pinnae & Measurement (cm) \\
\hline 16. & Length of pinnules & Measurement (mm) \\
\hline 17. & Width of pinnules & Measurement (mm) \\
\hline 18. & Distance between pinnules & Measurement (mm) \\
\hline 19. & Costa surface & Glabrous; laminar \\
\hline 20. & Pinna's veins & Convex; flat \\
\hline 21. & Pinna‘s apex & Acute, acuminate; aristate \\
\hline 22. & Pinna's margin & Equal; unequal \\
\hline 23. & Color of pinna's abaxial surface & Whitish green; light green \\
\hline 24. & Hairs on pinna's abaxial surface & Hairy; almost glabrous \\
\hline 25. & Hairs color on pinna's abaxial surface & Reddish-brown; brown; whitish brown \\
\hline 26. & Position of first forking on pinnule's vein & At the bottom of pinnule; at the middle of pinnule \\
\hline 27. & Veins color on pinna's adaxial surface when dry & Brown; white \\
\hline 28. & The nature of veins on pinna's adaxial surface when dry & Convex; flat \\
\hline 29. & Curvature of the pinna veins on abaxial surface & Curved; flat \\
\hline 30. & Pinnule's apex & Retuse; truncate \\
\hline 31. & The number of forking on pinnule's veins & $\begin{array}{l}\text { Once-forking; twice forking; three times-forking; } \\
\text { Four times-forking; five times-forking }\end{array}$ \\
\hline 32. & Length of scales & Measurement (mm) \\
\hline 33. & Position of sori on pinnules & $\begin{array}{l}\text { Third quarter from base; halfway from apex; } \\
\text { Halfway from base; along the pinnule }\end{array}$ \\
\hline 34. & The number of sporangia per sorus & Number (4-17) \\
\hline 35. & The number of sporangial stacks & $1 ; 2$ \\
\hline 36. & Sori color & Greenish white; yellowish-white \\
\hline 37. & Spore type & Monolete; trilete \\
\hline 38. & Length of spore's polar axis $(\mathrm{P})$ & Measurement $(\mu \mathrm{m})$ \\
\hline 39. & Diameter of spore's equatorial plane (E) & Measurement $(\mu \mathrm{m})$ \\
\hline 40. & Spore shape based on $\mathrm{P} / \mathrm{E}$ ratio & Sub-prolate; prolate; prolate-spheroidal; oblate-spheroidal \\
\hline 41. & Exine ornamentation & Psilate; micro-scabrate; scabrate; verrucate \\
\hline 42. & Class of spore size & Small; medium \\
\hline
\end{tabular}




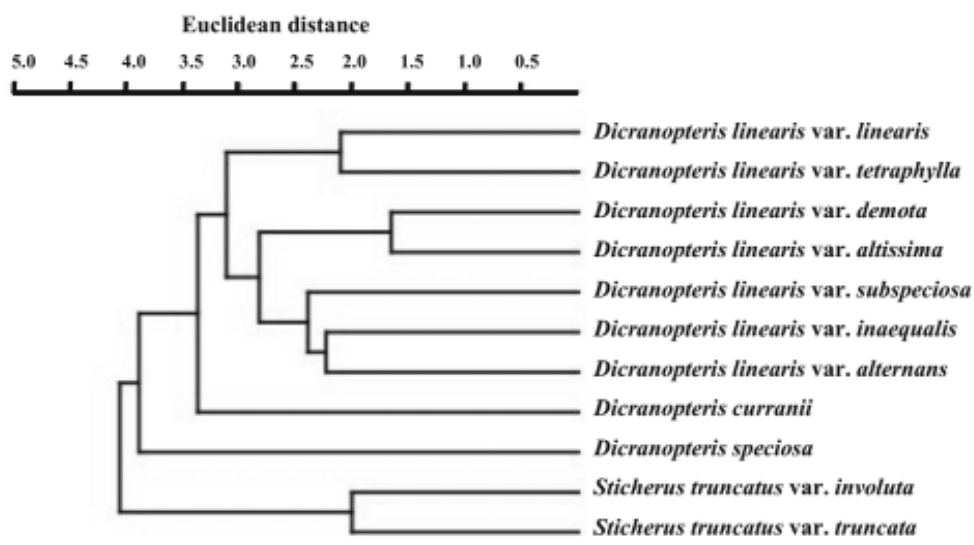

Figure 8. Dendrogram of taxonomic relationships of Dicranopteris and Sticherus species based on morphological and spore characters

Tabel 4. Character loadings on the first two principal components

\begin{tabular}{lll}
\hline Character & \multicolumn{2}{l}{ Principal component } \\
\cline { 2 - 3 } PC1 & PC2 \\
\hline Plant habit & -0.042 & 0.101 \\
Height of the first branch & -0.057 & 0.038 \\
The number of primary forks & -0.052 & 0.212 \\
Stipule on the first branch & 0.039 & -0.037 \\
Distance between branches & -0.035 & 0.118 \\
Angle of the primary branch & -0.036 & 0.066 \\
Rachis bud's surface & -0.159 & -0.077 \\
Rachis bud's protective structure & -0.280 & -0.092 \\
Branching pattern & 0.044 & 0.055 \\
Branch surface & -0.150 & 0.069 \\
Accessory branches & -0.153 & 0.015 \\
Accessory leaflets & 0.107 & -0.094 \\
Number of branches at each fork & -0.030 & -0.061 \\
Length of primary pinnae & 0.251 & -0.057 \\
Width of primary pinnae & 0.465 & -0.036 \\
Length of pinnules & 0.153 & -0.026 \\
Width of pinnules & 0.034 & 0.360 \\
Distance between pinnules & 0.026 & -0.312 \\
Costa surface & -0.140 & -0.027 \\
Pinna's veins & 0.076 & 0.150 \\
Pinna's apex & 0.121 & 0.121 \\
Pinna's margin & 0.110 & -0.153 \\
Color of pinna's abaxial surface & -0.159 & -0.077 \\
Hairs on pinna's abaxial surface & 0.076 & 0.150 \\
Hairs color on pinna's abaxial surface & -0.150 & 0.069 \\
Position of first forking on pinnule's vein & -0.100 & 0.067 \\
Veins color on pinna's adaxial surface when dry & 0.044 & 0.055 \\
The nature of veins on pinna's adaxial & -0.134 & -0.179 \\
surface when dry & & \\
Curvature of the pinna veins on abaxial surface & -0.094 & 0.141 \\
Pinnule's apex & -0.112 & -0.240 \\
The number of forking on pinnule's veins & 0.324 & -0.154 \\
Length of scales & -0.216 & -0.077 \\
Position of sori on pinnules & -0.091 & 0.289 \\
The number of sporangia per sorus & 0.286 & 0.102 \\
The number of sporangial stacks & 0.236 & 0.003 \\
Sori color & 0.102 & -0.091 \\
Spore type & -0.134 & -0.179 \\
Length of spore polar axis (P) & 0.064 & -0.139 \\
Diameter of spore equatorial plane (E) & -0.106 & -0.148 \\
Spore shape based on P/E ratio & -0.121 & -0.210 \\
Exine ornamentation & -0.073 & 0.421 \\
Class of spore size & 0.064 & -0.139 \\
Eigenvalue & 1,873 & 1,227 \\
\% Variance & 30,604 & 20,047 \\
\% Cumulative Variance & 66,882 & 50,651 \\
\hline & &
\end{tabular}

Overall, this study emphasized the use of morphology and spore characters in assessing taxonomic relationships of ferns analyzed using numerical taxonomic methods. The application of multivariate methods in analyzing phenetic relationships of ferns based on morphology and spore characters has been reported for many taxa. Petchsri et al. (2012) reported the use of cluster analysis and canonical discriminant analysis in resolving taxonomic status and species delimitation in Microsorum punctatum species complex. Wei and Zhang (2013) used cluster analysis, principal coordinate analysis, and principal component analysis based on morphological variation for species delimitation in the fern genus Lemmaphyllum. Sen and Mukhopadhyay (2016) reported the use of morphology and spore characters and the use of numerical taxonomy methods in resolving taxonomic relationships of Indian cheilanthoid fern. It could be concluded, therefore, that results of this study provided evidence on the efficiency of combining sporophyte morphology and spore characters in ferns systematics study. This study also supported the use of more than one numerical taxonomic method in defining relationships between closely related species and genera.

\section{ACKNOWLEDGEMENTS}

This research was partially supported by the funding from LPDP Scholarship 2020 (for field trip in Riau, Indonesia) granted for the first author, and by Research Funding from Universitas Gadjah Mada (for spore microscopic analysis and publication) under the scheme of Thesis Recognition Program (RTA 2021) granted for the second author.

\section{REFERENCES}

Adeonipekun PA, Adebayo MB, Oyebanji OO. 2021. Spore characterization and its taxonomic significance in ferns from Lagos State, Nigeria. Grana 60 (4): 271-286. DOI: 10.1080/00173134.2020.1844794

Albuquerque MA, Barros KNNO, Gouveia JF, Ferreira RLC. 2016. Determination and validation of group numbers in cluster analysis: A 
case study applied to forestry science. Acta Sci Technol 38 (3): 339344. DOI: $10.4025 /$ actascitechnol.v38i3.28359

Alzahrani DA, Albokhari EJ, Khoj A. 2021. Taxonomic studies on some members of the genus Abutilon Mill. (Malvaceae). Am J Plant Sci. 2: 199-220. DOI: 10.4236/ajps.2021.122012

Andriyani F, Nurza ISA. 2021. Identification and inventory of Pteridophyta in Mount Gede Pangrango National Park, Cibodas, West Java. Risenologi 6 (1): 46-56. DOI: 10.47028/j.risenologi.2021.61.145

Arogundade OO, Adedeji O. 2019. Numerical taxonomic studies of some members from four tribes of the family Araceae in southwestern Nigeria. J Biol Stud 2 (1): 9-24.

Bautista MG, Coritico FP, Acma FM, Amoroso VB. 2018. Spikemoss flora (Selaginella) in Mindanao Island, the Philippines: species composition and phenetic analysis of morphological variations. Philipp J Syst Biol 12 (1): 45-53.

Bean AR. 2010. Collecting and Preserving Plant Specimens, A Manual, Version 4. Queensland Herbarium, Department of Environmental and Resource Management, Brisbane.

Beukema H, van Andel J, Werger MJ, van Noordwijk M. 2013. Ferns as indicators of habitat quality in

(agro)forest in Sumatra. ASB Policybrief No. 37. Nairobi: ASB Partnership for the Tropical Forest Margins.

Chao YS, Huang YM. 2018. Spore morphology and its systematic implication in Pteris (Pteridaceae). PLoS ONE 13 (11): e0207712. DOI: 10.1371/journal.pone.0207712

Chinnock RJ, Bell GH. 1998. Gleicheniaceae. In: McCarthy PM. (eds) Flora of Australia Volume 48, Ferns, Gymnosperms and Allied Groups. Melbourne, ABRS/CSIRO Australia.

Christenhusz MJM, Chase MW. 2014.Trends and concepts in fern classification. Ann Bot 113: 571-594. DOI:10.1093/aob/mct299.

Coritico FP, Amoroso VB. 2020. Threatened lycophytes and ferns in four protected areas of Mindanao, Philippines. Nat. Conserv Res 5 (4): 78 88. DOI: $10.24189 /$ ncr.2020.061

de Winter WP, Amoroso VB (eds). 2003. Plant Resources of Southeas Asia. Cryptogams: Ferns and Fern-Allies. Backhuys Publishers, Leiden.

Diliarosta S, Ramadhani R, Indriani D. 2020. Diversity of Pteridophyta in Lubuak Mato Kuciang Padang Panjang, Sumatera Barat. Pharmacog J 12 (1):180-5. DOI: $10.5530 / \mathrm{pj} .2020 .12 .27$

Dong Sy, Haque AKMK, Rahman MS, Rahim MA, Khan SA. 2020. A taxonomic revision of the fern genus Tectaria (Tectariaceae) from Bangladesh. Taiwania 65 (4): 567-574. DOI: 10.6165/tai.2020.65.567

Erdtman G. 1986. Pollen Morphology and Plant Taxonomy: Angiosperms. New York: Hafner Publishing Company.

Farfán-Santillán N, Mendoza-Ruiz A, Pérez-García B, Velázquez-Montes E. 2016. Palynología de las especies Mexicanas de Gleicheniaceae. Bot. Stud. 94 (2): 281-289. DOI: 10.17129/botsci.509

Fitriana N, Susandarini, R. 2019. Short Communication: Morphology and taxonomic relationships of shallot (Allium cepa $\mathrm{L}$. group aggregatum) cultivars from Indonesia. Biodiversitas 20: 2809-2814. DOI $10.13057 /$ biodiv/d201005

Gonzales J, Kessler M. 2011. A synopsis of the Neotropical species of Sticherus (Gleicheniaceae), with description of nine new species. Phytotaxa 31: 1-54

Halbritter H, Ulrich S, Grímsson F, Weber M, Zetter R, Hesse M, Buchner R, Svojtka M, Frosch-Radivo A. 2018. Illustrated Pollen Terminology $2^{\text {nd }}$ eds. Cham: Spinger International Publisher AG.

Hammer Ø, Harper DAT, Ryan PD. 2001. Past: Palaeontological Statistics Software Package for Education and Data Analysis. Paleontologia Electronica 4 (1): 4-9

Holttum, R. E. 1957. Florae Malesianae Praecursores XVI. On the taxonomic subdivision of the Gleicheniaceaeeae, with description of new Malaysian species and varieties. Reinwardtia 4: 257-280. DOI: 10.14203/reinwardtia.v4i2.1004

Holttum RE. 1959. Gleicheniaceae. In: Van Steenis CGGJ, Holttum RE. (eds.). Flora Malesiana Ser. II Pteridophyta 1 (1). Martinus Nijhoff/Dr. W. Junk Publishers, The Hague, Australian.

Jaman R, Imin K, Kiew R. 2017. Asplenium merapohense (Aspleniaceae), a new species from the Peninsular

Malaysia. PhytoKeys 89: 85-90. DOI: 10.3897/phytokeys.89.20875

Jin XF, Ding BY, Iwatsuki K. 2013. Gleicheniaceae. In: Wu ZY, Raven PH, Hong DY. (Eds.). Flora of China (Pteridophytes). Beijing: Science Press; St. Louis: Missouri Botanical Garden Press.

Jones GD. 2014. Pollen analyses for pollination research, acetolysis. J. Pollinat. Ecol. 13 (21): 203-217.
Lashin GMA. 2012. Palynological studies of some species of Aspleniaceae - Pteridophyta. Am. J. Plant Sci. 3: 397-402. DOI; 10.4236/ajps.2012.33048

Li XJ, Li N, Wang BH, Li JX. 2020. Study on the spore morphology of Ceratopteris Brongn. Proceedings of the IOP Conf. Series: Earth and Environmental Sciences 559: 0120222. DOI: 10.1088/17551315/559/1/012022

Lima VL, Salino A. 2018. The fern family Gleicheniaceae (Polypodiopsida) in Brazil. Phytotaxa 358 (3): 199-234. DOI: 10.11646/phytotaxa.358.3.1

Liu H, Rakotondrainibe F, Hennequin S, Schneider H. 2020. The significance of Rouxopteris (Gleicheniaceae, Polypodiopsida): A new genus endemic to the Madagascar region. Plant Syst Evol 306: 30. DOI: $10.1007 / \mathrm{s} 00606-020-01657-9$

Manoko MLK. 2018. The power of coefficients and methods of coding in delimiting species using phenetic approach: The case of African Solanum section Solanum sensu Edmonds. Tanz. J Sci 44 (1): 37-51.

Mazumdar J. 2018. Based on Spore morphology Lygodium giganteum not a synonym of Lygodium yunnanense (Lygodiaceae). Int J Adv Res Innov Ideas Edu 4 (3): 927-928

Mildawati, Sobir, Sulistijorini, Chikmawati T. 2020. The diversity of pteridophytes in Siberut National Park, Mentawai Islands, West Sumatra, Indonesia. Biodiversitas 21: 3200-3208. DOI: 10.13057/biodiv/d210742

Mulima E, Sibiya J, Musvosvi C, Nhamucho E. 2018. Identification of important morphological traits in Mozambican sorghum [Sorghum bicolor (L.) Moench] germplasm using multivariate analysis. Afr J Agric Res 13 (34): 1796-1810. DOI: 10.5897/AJAR2018.13316

Nazihah I, Zaini MS, Shahari R, Amri CNAC, Tajuddin NM. 2018. Diversity and distribution of fern species in selected trail in Kuantan Pahang. Sci. Herit J 2 (1): 4-9. DOI: 10.26480/gws.01.2018.04.09

Østergaard A dan Øllgaard B. 1996. A note on some morphological terms of the leaf in the Gleicheniaceaeeae. Am Fern J 86: 52-57. DOI: $10.2307 / 1547368$

Passarelli LM, Galán JMG, Prada C, Rolleri CH. 2010. Spore morphology and ornamentation in the genus Blechnum (Blechnaceae). Grana 49 (4): 243-262. DOI: 10.1080/00173134.2010.524245

Perrie LR. 2018. Transfer of Papua New Guinea's Gleichenia hooglandii to Sticherus (Gleicheniaceae). Blumea 63: 120. DOI: 10.3767/blumea.2018.63.02.04

Perrie LR, Brownsey PJ. 2015. Gleicheniaceae. In: Breitwieser I, Heenan PB, Wilton A.D. (eds). Flora of New Zealand-Ferns and Lycophytes. Fascicle 12. Manaaki Whenua Press, Lincoln. DOI: 10.7931/B1 VC77

Petchsri S, Boonkerd T, Baum BR. 2012. Phenetic study of the Microsorum punctatum complex (Polypodiaceae). ScienceAsia 38: 112. DOI: $10.2306 /$ scienceasia1513-1874.212.38.001

Pochynok T. 2012. Is there a place for plant morphology in the contemporary research? Mod. Phytomorphol. 2: 13-16.

PPG I (The Pteridophyte Phylogeny Group). 2016. A community-derived classification for extant lycophytes and ferns. J Syst Evol 54 (6): 563-603. DOI: $10.1111 /$ jse.12229

Punt W, Hoen PP, Blackmore S, Nilsson S, Le Thomas A. 2007. Glossary of spore and pollen terminology. Rev. Palaeobot. Palynol. 143: 1-81. DOI: 10.1016/j.revpalbo.2006.06.008

Rahmad Z, Akomolafe GF. 2019. Taxonomic diversity of ferns of two recreational forests in Kedah, Malaysia. Malaysian J Sci 38 (3): 1-11.

Regalado L, Sánchez C. 2002. Spore morphology as a taxonomic tool in the delimitation of three Asplenium L. species complexes (Aspleniaceae: Pteridophyta) in Cuba. Grana 41 (2): 107-113. DOI: 10.1080/001731302760156909

Saharizan N, Karim MFA, Madzri NH, Fikri NA, Adnan NS, Ali NB, Abas MA, Amaludin NA, Zakaria R. 2021. Species diversity of pteridophytes in oil palm plantations at Segamat, Johor. IOP Conf. Series: Earth and Environmental Science 756: 012038. DOI:10.1088/1755-1315/756/1/012038.

Saraçli S, Doğan N, Doğan I. 2013. Comparison of hierarchical cluster analysis methods by cophenetic correlation. J. Inequal. Appl. 2013: 203.

Santos RO, Gorgulho BM, Castro MA, Fisberg RM, Marchioni DM, Baltar VT. 2019. Principal component analysis and factor analysis: Differences and similarities in nutritional epidemiology application. Rev Bras.Epidemiol 22: E190041. DOI: 10.1590/1980549720190041

Schneider H, Smith AR, Pryer KM. 2009. Is morphology really at odds with molecules in estimating fern phylogeny? Syst. Bot. 34 (3): 455 475. 
Sen K, Mukhopadhyay R. 2016. Indian cheilanthoid fern-A numerical taxonomic approach. Bangladesh J. Plant Taxon. 23 (2): 133-142.

Shaw SW, Ranker TA. 2011. New and Improved Leaf Terminology for Gleicheniaceaeeae. Am. Fern J. 101 (2): 117-124. DOI 10.1640/0002-8444-101.2.117

Shepherd LD, Brownsey PJ, Stowe C, Newell C, Perrie LR. 2019. Genetic and morphological identification of a recurrent Dicksonia tree fern hybrid in New Zealand. PLoS ONE 14 (5): e0216903. DOI: 10.1371/journal.pone.0216903

Simpson MG. 2019. Plant Systematics $3^{\text {rd }}$ ed. Academic Press, Oxford UK.

Singh G. 2010. Plant Systematics: An Integrated Approach $3^{\text {rd }}$ ed. Science Publishers, New Hampshire, USA.

Singh PK, Shrestha J, Kushwaha UKS. 2020. Multivariate analysis of soybean genotypes. J. Agric. Nat. Resour. 3 (1): 69-76. DOI: 10.3126/janr.v3i1.27092

Skog JE. 2001. Bioegeography of Mesozoic leptosporangiate ferns related to extant ferns. Brittonia 53: 236-269.

Smith AR, Pryer KM, Schuettpelz E, Korall P, Schneider H, Wolf PG. 2006. A classification for extant ferns. Taxon 55 (3): 705-731.

Sofiyanti N, Iriani D, Fitmawati, Marpaung AA. 2019. Morphology, palynology, and stipe anatomy of four common ferns from
Pekanbaru, Riau Province, Indonesia. Biodiversitas 20 (1): 327-336. DOI: $10.13057 /$ biodiv/d200138

Suryana, Mayawati B, Kusmoro J, Irawan B. 2020. Diveristy of ferns (Pteridophyta) in the several mountains of West Java. BioLink 7 (1): 71-80.

Ugwuanyim GU. 2000. The usefulness of clustering and principal component analysis in the classification of plants to species level. Afr J Nat Sci 3: 29-36.

Wang AH, Sun Y, Schneider H, Zhai JW, Liu DM, Zhou JS, Fu-Wu Xing FW, Chen HF, Wang FG. 2015. Identification of the relationship between Chinese Adiantum reniforme var. sinense and Canary Adiantum reniforme. BMC Plant Biol. 15:36. DOI: 10.1186/s12870014-0361-9

Wardani W, Adjie B. 2017. Checklist of Pteridophyte Flora of Enggano Island. Floribunda 5 (6): 209-219.

Wei XP, Zhang XC. 2013. Species delimitation in the fern genus Lemmaphyllum (Polypodiaceae) based on multivariate analysis of morphological variation. J Syst. Evol 51 (4): 485-496. DOI: 10.1111/jse.12019

Yang L, Huang Y, Lima LV, Sun Z, Liu M, Wang J, Liu N, Ren H. 2021. Rethinking the ecosystem functions of Dicranopteris, a widespread genus of ferns. Front. Plant Sci. 11: 581513. DOI: $10.3389 /$ fpls.2020.581513 